\title{
Exploring mediating effects between nursing leadership and patient safety from a person-centred perspective: A literature review
}

\section{Running title: A review of leadership and patient safety}

\section{Author 1}

Meini Wang* MSc Student, School of Health Sciences, Queen Margaret University, Edinburgh, $\mathbf{U K}$

Author 2 Professor Jan Dewing PhD, Sue Pembrey Chair of Nursing, School of Health Sciences, Queen Margaret University Edinburgh, UK

*Corresponding author: Queen Margaret University, Edinburgh, Scotland

Email: 17011897@QMU.ac.uk

Conflict of interests: nothing to declare

Funding sources: no external funding

Ethical Approval: ethical approval was not required because this was a low risk systematic literature review as part of a Master programme. The proposal was approved through the university and the review was supervised by a Professor of Nursing Research at the university

This article has been accepted for publication and undergone full peer review but has not been through the copyediting, typesetting, pagination and proofreading process, which may lead to differences between this version and the Version of Record. Please cite this article as doi: $\underline{10.1111 / \text { JONM.13226 }}$

This article is protected by copyright. All rights reserved 
MS MEINI WANG (Orcid ID : 0000-0002-4022-8160)

Article type : Review Article

\title{
Exploring mediating effects between nursing leadership and patient safety from a person-centred perspective: A literature review
}

\begin{abstract}
Aims: To evaluate the mechanism through which nursing leadership impacts patient safety.

Background: Patient safety has received considerable attention among policy makers, governments and public sectors with the emphasis in healthcare settings on minimising the risk to patients. Claims are made leadership plays a crucial role in patient safety However, the incidents of adverse events are consistently high in hospitals.
\end{abstract}

Evaluation: Published English-only research articles that examine the mechanism by which nursing leadership impacts patient safety were selected from seven electronic databases and manual searches. Data extraction, quality assessments and analysis were completed for ten research studies.

Key Issues: There is evidence of significant mediating effects between nursing leadership and decreased adverse patient outcomes specifically with regard to workplace empowerment, leadernurse relationship and the quality of the care environment. 
Conclusion: The findings suggest that nursing leadership has a significant indirect impact on patient safety outcomes. From a person-centred perspective the care environment requires workplace empowerment and effective relationships between leaders and nurses.

Implications for Nursing Management: To improve patient safety outcomes, managers must strive to emphasise workplace empowerment, leader-nurse relationship and the quality of the care environment. Managers must consider these domains as part of an effective workplace culture.

Key words: nursing leadership, person-centred, patient safety, outcome, safety indicators; care environment, empowerment

\section{Background}

Patient safety has received considerable attention among policy makers, governments and public sector organisations; with an emphasis in healthcare placed on risk reduction including the minimisation of the risks patients are exposed to (Forster et al., 2012). Adverse patient outcomes or events are defined as unintentional injuries or complications caused by healthcare providers, rather than the patient's underlying condition resulting in death or disability or prolonged hospital stay (Baker et al., 2004). Indeed, Baker et al., (2004) identify that the incidents of adverse events are often reported to be consistently high in hospitals despite huge efforts to reduce them. According to The Canadian Institute for Health Information (2016), one in every 18 (about 30,000) patients suffers avoidable harm which affects their care in more than 138,000 hospitalisations in Canada in 2014 to 2015. For example, two prospective studies found that between $28 \%$ and $80 \%$ of adverse drug events are preventable (Gurwits et al., 2000, Lagnaoui et al., 2000). Additionally, it is estimated by Soop et al (2009) in a European research study that an adverse event occurs in between $10 \%$ to $70 \%$ of all hospitalisation.

Nurses are the largest workforce group creating safer practice environments for patients and possibly have the best opportunities to improve patient safety in healthcare settings (Vaismoradi et al., 2011). Studies highlight that the high rate of adverse events in healthcare 
institutions is preventable (Aiken et al., 2002) including those that are related to factors stemming from the nurses' work environment (Needleman et al., 2002). The Institute of Medicine (IoM) (2004) have stressed for more than decade, that modification of the nursing work environment including strong nursing leadership would improve patient safety. Indeed, two literature reviews (Wong \& Cummings, 2007; Wong et al., 2013) found that there is a significant association between positive relational nursing leadership and reduced adverse patient outcomes. From a dialogical moral practice perspective, relational leadership is a way of being and relation with each other, embedded in experience and interlinked with sense of moral responsibility (Cunliffe \& Eriksen, 2011). Relational leadership styles such as transformational leadership, are not only relevant to current complex healthcare workplaces and improved patient safety (Schein, 2010), but align well with the fundamental principles of person-centredness as a nursing concept (McCormack \& McCance, 2010, 2017; Beckett et al., 2013) and is frequently found in personcentred practice literature (McCormack et al., 2015). Person-centred nursing practice has become increasingly common in healthcare and aligns itself with humanising healthcare. Significantly, The World Health Organization (2007, p. 7) has promoted the global goal of humanising healthcare by ensuring that it is rooted in universal principles of human rights and dignity, nondiscrimination, participation and empowerment, access and equity, and a partnership of equals. Thus, patient safety and nursing leadership need to be considered in the broader context of person-centredness or in other words, as part of person-centred culture. McCormack and McCance (2017) developed a mid range theory, the Person-centred Nursing Framework with four domains: 1) prerequisites focusing on the attributes of staff, 2) the care environment focusing on the care delivery context, 3) person-centred processes focusing on delivering care from variety of activities, 4) expected outcomes of person-centred nursing. The background evidence offered here, suggests a significant knowledge gap about how leadership in nursing impacts patient safety outcomes from the perspective of person-centredness.

\section{Purpose}

The purpose of this literature review is to analyse the findings from a review of ten studies that examine the mechanism(s) by which nursing leadership impacts patient safety, with a view to explaining connections to the concept of person-centredness via the Person-centred Nursing Framework (McCormack \& McCance, 2017).

This article is protected by copyright. All rights reserved 


\section{Methods}

\section{Design}

An integrative review of literature was chosen as this methodology provides for the synthesis of knowledge and consideration of the applicability of the results to practice.

\section{Search strategy}

A three-step search strategy was utilised in this review with key words: nursing leadership, person-centred, patient safety outcome, patient safety indicators. A preliminary search with limited keywords on CINAHL and MEDLINE was conducted to gain a sense of the range of literature that existed. This was followed by second search using all defined search terms and combinations of terms with the following data bases: CINAHL, MEDLINE, ProQuest Central, PubMed, PsycINFO, Ovid and Web of Science. The online search yielded 3953 titles/abstracts. We identified ten additional studies via hand searching. Once we removed duplicates, we were left with 2791 titles. The titles and abstracts were screened using the inclusion criteria.

[insert Box 1 here]

\section{Screening}

The first author reviewed all 2791 titles and abstracts twice working with the inclusion criterion. Twenty-two studies that addressed both nursing leadership and patient safety outcomes were selected. The reference lists of all these retrieved studies were hand-searched to further identify any more articles that were relevant to the research questions. All twenty-two full text studies were reviewed by author based on inclusion criterion and twelve articles were excluded because they did not meet the inclusion criteria (see Figure 1 for search and retrieval process). Ten studies were final included for this review.

\section{Data extraction}

Data was extracted from all articles included in this literature review using a standardised data extraction tool from Joanna Briggs Institute (JBI). The JBI tool is used to promote the extraction of similar data across all included studies in a review (JBI, 2019). These data include 
specific details about the phenomena of interest, populations, study design and outcomes of significance to the review question and specific objectives.

\section{Quality review}

Each included article was reviewed by the first author twice using JBI critical appraisal checklist for cross-sectional (JBI, 2017a) and qualitative study (JBI, 2017b) accordingly. This appraisal tool rates each component under four categories such as yes, no, unclear and not applicable. Eight criterion were included in the checklist for cross-sectional study and ten criterion were included in the checklist for qualitative study. The study was included if it has achieved a 'Yes' five times or more. One study achieved 'Yes' in eight out of ten questions. The second author validated the quality review and assessment process. This was achieved through a critical dialogue. Attention was given to the literature included in the review to ensure it was eligible.

\section{Results}

\section{Summary of the quality review}

Of the ten included studies (See Table 1), published between 2004 and 2019, six were conducted in Canada, the others were conducted in Korea $(n=1)$, Finland $(n=1)$ and Pakistan $(n=2)$. Seven out of ten studies focused on the mechanism of how transformational leadership impacts adverse patient outcomes and used cross-sectional and predictive non-experimental surveys on Registered Nurses (RN) working in direct patient care in acute hospitals. One study discussed on how authentic leadership had influenced adverse patient outcomes using a crosssectional survey of RNs working in acute hospitals. The demographics of the predominately female nurses in the studies were reported in all ten reviewed studies. The mean age and of nurses was reported in nine studies with a global mean of 42.2 years.

In this review, all but two studies managed to recruit the adequate number of sample size of more than 200 participants in the study. Kline (2005) stressed that a sample size of at least 200 or more subjects was generally sufficient. All but one study utilised a Likert scale to measure study variables; with validity and reliability supported by a previous study (Bamford, 2013). All 
researchers used more than one analysis test to analyse the data; and multivariate regression analysis was used to account for the confounding factors measured. The most obvious weakness in the reviewed studies related to study design. All but one studies used cross-sectional study design which precludes strong statements of causality. It is therefore difficult to conclude the relationship from cross-sectional analysis due to its one-time measurement of exposure and outcome (Setia, 2016). Moreover, only $20 \%$ of studies had a response rate of more than $60 \%$. Low response rate and self-assessed measures for patient outcomes might limit the representative of findings. One study tested how resonant leadership impacts adverse patient outcomes by cross-sectional survey of acute care RNs. One study did not specify the leadership type, while discussing the mechanism of leadership on adverse patient outcome through cross-sectional survey of hospital-based nurses. The findings of this literature review document the evidence of indirect positive effects between nursing leadership and patient safety outcomes through different mediators which will be presented next.

\section{Workplace empowerment}

By providing nurses with easy access to four organisational structures: information, support, resources and opportunities, nurse leaders also influenced nurses to complete their work efficiently and effectively (Kanter, 1993). Doing a job in an empowering work-atmosphere, means nurses can provide good quality of patient care which in turn acts to minimise adverse patient outcomes. Four studies examined the mediating mechanism of structural empowerment between leadership and adverse patient outcomes (Boamah et al., 2018; Khanzada et al., 2018; Boamah, 2018; Asif et al., 2019). These studies found that nurse managers were able to create the practice environment that enables nurses to feel empowered to provide optimal care for patients, which in turn reduces adverse patient outcomes. Moreover, nurse leaders also improved nurses' job satisfaction (Boamah et al., 2018; Khanzada et al., 2018), staff nurse clinical leadership (Boamah, 2018) through having an empowering environment. Again, these factors in turn, reduce adverse patient outcomes. Thus, researchers claim that structural empowerment is the key predictor of nurses' job satisfaction in the healthcare delivery system (Armstrong \& Laschinger, 2006). This is in line with earlier research by (Laschinger et al., 2003). More recently, Patrick et al. (2011) argue that structural empowerment fully mediated nursing leadership on development of staff nurse clinical leadership. Structural empowerment is also 
highly associated with the working conditions and the care environment, which enables nurses to practice professionally and enhance their autonomy (Boamah, 2018).

\section{Leader-nurse relationship}

Relational aspect of both nursing leadership are supported by the argument from (Jones $\&$ Bennett, 2012) that leadership is interested in human relationship and dynamics. Two studies (Wong \& Giallonardo, 2013; Squires et al., 2010), found that quality relationships between nurse leaders and staff would negatively mediate leadership impact on patient adverse outcomes. In the Wong and Giallonardo (2013) study, nursing leadership had a strong, significant positive direct impact on nurses' trust in the manager and in turn, trust in the manager had a negative indirect effect on adverse patient outcomes through positive working conditions. Trust in the manager contributed a positive direct effect on nurse's working conditions. The study by Vogus and Sutcliffe (2007) also supports that the reliability of the manager increased the benefits of safety organising practices, which in turn reduced medication error. Squires et al. (2010) found nursing leadership enhanced the quality of leader-nurse relationship which further affected safety climate and work environment. This ultimately improves patient and nurse outcomes such as medication error, emotional exhaustion and intention to leave the job.

\section{Quality of practicing environment}

Nurse leaders must develop strategic interventions to provide the quality of work environment and infrastructure that will enable nurses to practice professionally, to provide optimal patient care and minimise adverse outcomes (Clifford, 1998). In Laschinger and Leiter's (2006) study, the researchers found that nursing leadership played a vital role in the quality of work life such as policy involvement, staffing levels, nursing model of care and nurse/physician relationships, which further negatively impacted adverse patient outcomes. It also highlighted that nurses' burnout directly mediated the quality of work life on patient adverse outcomes significantly. This finding aligns with those from Aiken et al. (2003) and Lake's (2002) studies, Both studies show that care environments impacted on patient outcomes, as well as having a mediating role with nursing staff burnout in this process (Leiter \& Laschinger, 2006). Higgins (2015) found that nursing leadership could reduce adverse patient outcomes through mediating the role of supportive practice environments. When nurse managers provide nurses with a 
supportive practicing environment, nurses can demonstrate organisational citizenship behaviours that further improve patient safety culture and nurses' job satisfaction. This result is also supported by the recommendation from the IOM (2004) that they encourage strong leadership, the work environment and a safety culture to be focused on patient safety outcomes. Two studies (Lappalainen et al., 2019; Kim et al., 2020) investigate the mediating role of the nursing process and the safety system in the care environment between nursing leadership and medication safety. In the Lappalainen et al. (2019) study, nurse managers promoted medication safety in the unit through implementation of the nursing process. In comparison, Kim et al. (2020) found that nursing leadership enhances the perceived benefits of safety with the medication system in use, which then contributes to a positive medication-error management climate. Subsequently, this reduced the medication error for patients. Here, the perceived benefits of the system in use becomes the mediator in the process.

\section{Discussion}

The ten methodologically sound qualitative studies in this review reflect the small volume of research available to advance our understanding of the mechanisms of nursing leadership's impact on patient safety outcomes. The main finding of interest in this review is that nursing leadership did not directly impact patient safety rather it has an indirect impact, through different mediating effects which can be mapped to the Person-centred Framework (McCormack and McCance 2017) as illustrated in Figure 2. This means that nurse managers and leaders must aim to address the mediating factors and know to evaluate these factors as a measure of their effectiveness. The findings on the mediating effect of structural empowerment show a significant negative impact between leadership and adverse patient outcomes in four studies. This important connection may suggest that effective nursing leadership is crucial to improving the care environment in regard to supporting the professional practice of nurses, which subsequently, contributes to better patient outcomes. This proposition is supported by Laschinger (2008), who found that nurses may experience increased structural empowerment under transformational leadership and that this leads to an improved working atmosphere and ultimately can result in more positive patient outcomes. Good leader-nurse relationships were found to be an indicator on patient safety outcomes in two studies. These trusting and respectful relationships should 
increase patient safety because nurses are more likely to feel psychologically safe themselves resulting in a sense of personal freedom to question current practice and discuss errors (Edmondson 2019). Vogus and Sutcliffe (2007) found that trusting relationship between nurse leaders and nurses increased the benefits of nurses safe practice which reduced adverse patient events. Finally there was a significant positive mediating effect on the quality of the care environment between nursing leadership and adverse patient outcomes in four studies; specifically supportive practice environment and quality of nurses' work life, management of the nursing process and the safety system. This finding may indicate that nurse leaders must develop plans to provide a quality care environment and infrastructure that will enable nurses to practice professionally, and thereby minimise adverse outcomes (Clifford, 1998).

Therefore, it is reasonable to recommend that effective leadership that extends to various typologies, is key to the creation of care environments where nurses and leaders have good relationships that are grounded in trust. This recommendation is supported by Germain and Cummings (2010), who found that nurses will perform more effectively where managers and leaders create what they refer to as an optimal care environment. In the following section we discuss the mechanism of nursing leadership and patient safety outcomes in the context of person-centred nursing.

\section{[Insert Figure 2 here]}

The care environment as described by McCormack and McCance (2017) focuses on the context in which care is delivered and consists of: appropriate skill mix; system that promote shared decision making; effective staff relationships, supportive organisational systems; the sharing of power; the potential for innovation and risk taking; and the physical environment. The attributes of leader-nurse relationships and workplace empowerment can be seen as sub attributes of the effective care environment within the framework. This review clearly reveals how nurse managers can promote patient safety outcomes through providing supportive and safer care environments. McCormack and McCance (2016), stress that a supportive workplace is crucial at the micro or team level. A sense of belonging and being part of a team is an aesthetic within the care environment and a key factor in contributing to nurses having a sense of identity, sense of being a person of value and a sense of connection to a team. Feeling psychologically safe, 
recognised and belonging are the core human needs (Edmondson 2019). Further, a recent Kings Fund report identifies autonomy, belonging and contribution as being core to nurses practicing as best they can (West et al 2020)

McCormack (2004) proposes that 'being in relation' and 'being in social world' are two of four core concepts at heart of person-centred nursing. It is evident from this review that person-centred nurse-leadership relationships foster an effective care environment and a positive safety climate which subsequently improves patient outcomes. This finding is consistent with recommendation from McCormack and McCance (2017) that we should not only focus on development of relationship with our patients, but also pay attention to our professional relationships. Anonson et al. (2014) argue that nurses desire to feel welcomed and connected to their leaders. Good nurse leader-nurse relationships also give nurses a sense of respect, trust and recognition; which is comparable with West et al (2020).

In this study, we found that workplace empowerment enables nurses to perform according to required professional standards and thus provide safer care for patients. In such supportive and empowering environments, nurses develop clinical leadership behaviours at the patient bedside and in the 'moment' they are required (ie they have the potential for innovation and risk taking) which ultimately improves patient safety outcomes and patient experience. Empowerment and shared decision making in the workplace is closely related to the presence of a learning culture according to Senge (2006). Senge (2006) debated that continuing learning only took place in a supportive context and where it was viewed as an integrated component of practice. The concept of shared decision making is clearly set out in the Person-centred Framework (McCormack \& McCance, 2016). By creating and nurturing the conditions that enable nurses to empower themselves, give nurses a sense of involvement and inclusiveness in achieving common goals such as patient safety. Therefore, nurse leaders should not only recognise, and respect nurses' contributions, but continue encouraging the attributes set out within the care environment (See Figure 2) consistent with person-centred practice concepts (McCormack \& McCance, 2010).

A large proportion of studies in this review focused on the mechanism through which nursing leadership enhanced structural empowerment and subsequently improved staff job satisfaction or staff nurse clinical leadership. Moreover, nursing leadership that pays more attention to nurses' quality of work life in order to prevent nurses' burnout will go some way to

This article is protected by copyright. All rights reserved 
safer patient care, hence, subsequently reducing adverse patient outcomes. Staff experience of job satisfaction and the impact of clinical leadership not only provides nurses with a good experience of work, but eventually fosters a healthful practice culture. Nurses as persons, need to feel valued for what they are doing and have a sense of happiness from their job (Boamah 2018).

Given patient safety is amongst the core goals of all healthcare professionals including nursing (Boamah, 2018), the connection between nursing leadership and safety can be considered a major driver or motivational factor. This review documents a promising picture of enhanced patient safety outcomes through paying attention to the various mediating effects of nursing leadership. However, we note a gap in the research here. That is the view and experience of persons receiving care, as the main stakeholders and end service users, was not investigated in regard to their own safety outcomes. And yet, working with belief and values is stressed as a core principle of person-centred nursing (McCormack \& McCance, 2016). Gubrium and Holstein (2000) argue that healthcare professional's stereotypic perceptions can easily become the basis for decision making if persons receiving care are not listened to and not encouraged to speak for themselves. Therefore, the values, beliefs and preferences in regard to their own safety should be considered when researchers investigate how nursing leadership impacts safety.

By connecting leadership practice to the Person-centred Nursing Framework in the context of patient safety, it could be suggested that nursing leadership in this review have some attributes of relational and contextual embedded practice that foster a healthful environmental culture and team growth. Further, both relational and contextual components of leadership style were consistent with person-centred leadership conceptual framework by Cardiff et al. (2018).

\section{Implications for nursing management}

The mechanism through which nursing leadership impacts patient safety may point to the importance of nurse managers and leaders understanding of the role of their relationship with nurses and the care environment in mediating better patient outcomes. The evidence also informs readers that specific attributes in the care environment have the best potential to enhance or limit the effect of nursing leadership on patient safety outcomes. The connection between nursing leadership and person-centred nursing practice further suggests the importance of the personcentred leadership practice in promoting safety outcomes for persons receiving care.

This article is protected by copyright. All rights reserved 


\section{Limitations}

The cross-sectional nature of the reviewed studies restricts the interpretation of the evidencebased causality and theoretical foundations among the study variables (Polit \& Beck, 2012). The data for reviewed studies were collected at an individual level through survey, which limits their power because it exclusively assesses exposures and responses of individuals (Haneuse \& Bartell, 2011). Moreover, the subjective or perception-based assessment only presents an estimation of data, which might be subject to bias.

\section{Conclusion}

In this literature review we identified a significant, although indirect effect of nursing leadership on patient safety outcomes through two mediators in the care environment; especially workplace empowerment and the leader-nurse relationships. By connecting nursing leadership to the Person-centred Framework in the context of safety, this review contributes to a small but growing evidence showing an association between certain types of nursing leadership and the Person-centred Practice Framework. Considering, the high number of adverse patient outcomes happenings in hospitals, it is vital that nurse managers ensure a person-centred care environment; specifically developing effective relationships with nurses and enhancing workplace empowerment in nurses, which in turn, improves safety outcomes.

This article is protected by copyright. All rights reserved 


\section{References}

Aiken, L.H., Clarke, S.P., Sloane, D.M., Sochalski, J., \& Silber, J.H. (2002). Hospital nurse staffing and patient mortality, nurse burnout, and job dissatisfaction. JAMA, $\quad 288,1987-$ 1993. https://doi.org/10.1001/jama.288.16.1987.

Aiken, L.H., Clarke, S.P., Cheung, R.B., Sloane, D.M., \& Silber, J.H. (2003).

Educational levels of hospital nurses and surgical patient mortality. JAMA, 290, 16171623. https://doi.org/10.1001/jama.290.12.1617.

Anonson, J., Walker, M.E., Arries, E., Maposa, S., Telford, P., \& Berry, L. (2014).

Qualities of exemplary nurse leaders: perspectives of frontline nurses. Journal of Nursing Management, 22, 127-136. https://doi.org/10.1111/jonm.12092.

Armstrong, K.J., \& Laschinger, H. (2006). Structural empowerment, Magnet hospital characteristics, and patient safety culture: making the link. Journal of Nursing Care Quality, 21, 124-132. https://doi.org/10.1097/00001786-200604000-00007.

Asif, M., Jameel, A., Hussain, A., Hwang, J., \& Sahito, N. (2019). Linking transformational leadership with nurse-assessed adverse patient outcomes and the quality of care: Assessing the role of job satisfaction and structural empowerment. International Journal of Environmental Research and Public Health, 16, 13. https://doi.org/10.3390/ijerph16132381.

Baker, G.R., Norton, P.G., Flintoft, V., Brown, A., Cox, J., Etchells, E.,...Tamblyn, R. (2004). The Canadian Adverse Events Study: the incidence of adverse events among hospital patients in Canada. CMAJ, 170, 1678-86. https://doi.org/10.1503/cmaj.1040498.

Bamford, M., Wong, C.A., \& Laschinger, H. (2013). The influence of authentic leadership and areas of worklife on work engagement of registered nurses. Journal of Nursing Management, 21, 529-540. https://doi.org/10.1111/j.1365-2834.2012.01399.x.

Beckett, P., Field, J., Molloy, L., Yu, N., Holmes, D., \& Pile, E. (2013). Practice What You Preach: Developing Person-Centred Culture in Inpatient Mental Health Settings through Strengths-Based, Transformational Leadership', Issues in Mental Health Nursing. August, vol. 34, no. 8, pp. 595-601. https://doi.org/10.3109/01612840.2013.790524.

Boamah, S. (2018). Linking nurses' clinical leadership to patient care quality: The role of

This article is protected by copyright. All rights reserved 
transformational leadership and workplace empowerment. The Canadian Journal of Nursing Research, 50, 9-19. https://doi.org/10.1177/0844562117732490.

Boamah, S.A., Laschinger, S.H.K., Wong, C., \& Clarke, S. (2018). Effect of transformational leadership on job satisfaction and patient safety outcomes. Nursing Outlook, 66, 180-189. https://doi.org/10.1016/j.outlook.2017.10.004.

Canadian Institute For Health Information. (2016). Measuring patient harm in Canadian hospitals: What can be done to improve patient safety? Ottawa: CIHI.

Cardiff, S., Mccormack, B., \& Mccance, T. (2018). Person-centred leadership: A relational approach to leadership derived through action research. Journal of Clinical Nursing, 27, 3056-3069. https://doi.org/10.1111/jocn.14492.

Clifford, J.C. (1998). Restructuring: the impact of hospital organization on nursing leadership. San Francisco, Calif: Jossey-Bass Publishing.

Cunliffe, A.L., \& Eriksen, M. (2011). Relational leadership. Human Relations. November, vol. 64, no. 11, pp. 1425-1449. https://doi.org/10.1177/0018726711418388.

Edmondson, A. C. (2019) The Fearless Organisation. Hoboken New Jersey: Wiley

Forster, A.J., Dervin, G., Martin, C., \& Papp, S. (2012). Improving patient safety through the literature evaluation of patient outcomes. Canadian Journal of Surgery, 55, 418-425. https://doi.org/10.1503/cjs.007811.

Germain, P.B., \& Cummings, G.G. (2010). The influence of nursing leadership on nurse performance: A literature literature review. Journal of Nursing Management (John Wiley \& Sons, Inc.), 18, 425-439. https://doi.org/10.1111/j.1365-2834.2010.01100.x.

Gubrium, J.F., \& Holstein, J.A., eds. (2000). Aging and everyday life. Oxford: Blackwell Publisher.

Gurwitz, J.H., Field, T.S., Avorn, J., McCormick, D., Jain, S., Eckler, M., Benser, M., Edmondson, A.C., \& Bates, D.W. (2000). Incidence and preventability of adverse drug events in nursing homes. Am J Med, 109, 87- 94. https://doi.org/10.1016/S0002-9343(00)00451-4.

Haneuse, S., \& Bartell, S. (2011). Designs for the combination of group- and individuallevel data. Epidemiology (Cambridge, Mass.), 22, 382-389. https://doi.org/10.1097/EDE.0b013e3182125cff.

Higgins, E.A. (2015). The Influence of Nurse Manager Transformational Leadership on

This article is protected by copyright. All rights reserved 
Nurse and Patient Outcomes: Mediating Effects of Supportive Practice Environments, Organizational Citizenship Behaviours, Patient Safety Culture and Nurse Job Satisfaction [online]. PhD thesis ed. Western University [viewed 12 January 2020]. Available from: https://ir.lib.uwo.ca/etd/3184

Institute of Medicine. (2004). Nursing: inseparably linked to patient safety. In page A, ed.

Keeping patients safe: transforming the work environment of nurses. Washington DC: National Academy Press.

Joanna Briggs Institute. (2017a). The Joanna Briggs Institute Critical Appraisal tools for use in JBI Systematic Reviews. Checklist for Analytical Cross Sectional Studies. Available from: https://joannabriggs.org/sites/default/files/201905/JBI_Critical_Appraisal-

Checklist_for_Analytical_Cross_Sectional_Studies2017_0.pdf

Joanna Briggs Institute. (2017b). The Joanna Briggs Institute Critical Appraisal tools for use in JBI Systematic Reviews Checklist for qualitative research. Available from: https://joannabriggs.org/sites/default/files/2019-05/JBI_Critical_AppraisalChecklist_for_Qualitative_Research2017_0.pdf Joanna Briggs Institute. (2019). JBI Manual for evidence Synthesis. Section 2.6.7 data extraction. Joanna Briggs Institute. Available from: https://wiki.joannabriggs.org/display/MANUAL/2.6.7+Data+extraction

Jones, L., \& Bennett, C.L., (2012). Leadership in Health and Social Care: an introduction for emerging leaders. Banbury: Scion Publishing.

Kanter, R.M., (1993). Men and women of the corporation. $2^{\text {nd }}$ ed. New York, NY: Basic Books.

Khanzada, B., Naeem, S., \& Butt, H. (2018). Impact of transpormational leadership on job satisfaction and patient safety outcomes in health sector of Pakistan. Journal of Health Education Research \& Development, 6. https://doi.org/10.4172/23805439.1000251.

Kline, R.B. (2005). Principles and practice of structural equation modeling $\left(2^{\text {nd }} e d\right)$. New York: The Guilford Press.

Kim, M.S., Seok, J.H., \& Kim, B.M. (2020). Mediating role of the perceived benefits of

This article is protected by copyright. All rights reserved 
using a medication safety system in the relationship between transformational leadership and the medication-error management climate. Journal of Research in Nursing, 25, 22 34. https://doi.org/10.1177/1744987118824621.

Lake, E.T. (2002). Development of the practice environment scale of the nursing work Index. Research in Nursing \& Health, 25, 176-188. https://doi.org/10.1002/nur.10032.

Lagnaoui, R., Moore, N., Fach, J., Longy- Boursier, M., \& Begaud., B. (2000). Adverse drug reactions in a department of systemic diseases- oriented internal medicine: prevalence, incidence, direct costs and avoidability. Eur J Clin Pharmacol, 56, 181- 186.

https://doi.org/10.1007/s002280050738.

Lappalainen, M., Harkanen, M., \& Kvist, T. (2019). The relationship between nurse manager's transformational leadership style and medication safety. Scandinavian Journal of Caring Sciences. https://doi.org/10.1111/scs.12737.

Laschinger, H.K.S. (2008). Effect of empowerment on professional practice environments, work satisfaction, and patient care quality: Further testing the Nursing Worklife Model. Journal of Nursing Care Quality, 23, 322-330. https://doi.org/10.1097/01.NCQ.0000318028.67910.6b.

Laschinger, H.K.S., Almost, J., \& Tuer-Hodes, D. (2003). Workplace empowerment and magnet hospital characteristics: Making the link. Journal of Nursing Administration, 33, 410-422. https://doi.org/10.1097/00005110-200307000-00011.

Laschinger, H.K.S., \& Leiter, M.P. (2006). The impact of nursing work environments on patient safety outcomes: The mediating role of burnout/engagement. Journal of Nursing Administration, 36, 259-267. https://doi.org/10.1097/00005110-200605000-00019.

Leiter, M.P., \& Laschinger, H.K.S. (2006). Relationships of work and practice environment to professional burnout: Testing a causal model. Nursing Research, 55, 137146. https://doi.org/10.1097/00006199-200603000-00009.

McCormack, B., Borg, M., Cardiff, S., Dewing, J., Jacobs, G., Janes, N., Karlsson, B., Mccance, T., Mekki, T.E., Porock, D., Van Lieshout, F., \& Wilson, V. (2015). Person-centredness - the 'state' of the art. International Practice Development Journal. May, vol. 5, pp. 1-15. https://doi.org/10.19043/ipdj.5sp.003.

McCormack, B., \& Mccance, T. (2010). Person-centred nursing: Theory and practice.

This article is protected by copyright. All rights reserved 
Oxford: Wiley-Blackwell.

McCormack, B., \& Mccance, T. (2016). Person-centred practice in nursing and health care: Theory and practice ( $2^{\text {nd }}$ ed). West Sussex: Wiley-Blackwell.

McCormack, B., \& Mccance, T. (2017). Person-centred practice in nursing and health care: Theory and practice ( $2^{\text {nd }}$ ed). Oxford: Wiley Blackwell.

Needleman, J., Buerhaus, P., Mattke, S., Stewart, M., \& Zelevinsky, K. (2002). Nursestaffing levels and the quality of care in hospitals. New England Journal of Medicine, 346, 1715-1722. https://doi.org/10.1056/NEJMsa012247.

Patrick, A., Laschinger, H.K.S., Wong, C., \& Finegan, J. (2011). Developing and testing a new measure of staff nurse clinical leadership: the clinical leadership survey. Journal of Nursing Management, 19, 449-460. https://doi.org/10.1111/j.1365-2834.2011.01238.x.

Polit, D.F., \& Beck, C.T. (2012). Nursing research: Generating and assessing evidence for nursing practice $\left(9^{\text {th }}\right.$ ed). Philadelphia, PA: Lippincott Williams \& Wilkins.

PRISMA. (2009). Transparent reporting of literature reviews and meta-analyses: PRISMA flow diagram [online] [viewed 2 December 2019]. Retrieved from: http://www.prisma-statement.org/PRISMAStatement/FlowDiagram.aspx

Schein, E.H. (2010). Organizational culture and leadership [online]. $3^{\text {rd }}$ ed. San Francisco:

John Wiley \& Sons [viewed 01 December, 2019]. Available from: http://untagsmd.ac.id/files/Perpustakaan_Digital_2/ORGANIZATIONAL\%20CULTURE\%2 0Organizational\%20Culture\%20and\%20Leadership,\%203rd\%20Edition.pdf

Senge, P. (2006). The fifth discipline. London: Random House Business Books.

Setia, M.S. (2016). Methodology Series Module 3: Cross-sectional Studies. Indian Journal of Dermatology, 1, 261-264. https://doi.org/10.4103/0019-5154.182410.

Soop, M., Fryksmark, U., Koster, M., \& Haglund, B. (2009). The incidence of adverse events in Swedish hospitals: a retrospective medical record review study'. International Journal for Quality in Health Care, 21, 285-291. https://doi.org/10.1093/intqhc/mzp025.

Squires, M., Tourangeau, A., Laschinger, H.K.S., \& Doran, D. (2010). The link between leadership and safety outcomes in hospitals. Journal of Nursing Management, 18, 914925. https://doi.org/10.1111/j.1365-2834.2010.01181.x.

Vaismoradi, M., Salsali, M., \& Marck, P. (2011). Patient safety: nursing students’

This article is protected by copyright. All rights reserved 
perspectives and the role of nursing education to provide safe care. International Nursing Review, 58, 434-442. https://doi.org/10.1111/j.1466-7657.2011.00882.x.

Vogus, T.J., \& Sutcliffe, K.M. (2007). The Safety Organizing Scale: development and validation of a behavioral measure of safety culture in hospital nursing units. Medical Care, 45, 46-54. https://doi.org/10.1097/01.mlr.0000244635.61178.7a

West, M., Bailey, S. \& Williams, E. (2020) The Courage of compassion Supporting nurses and midwives to deliver high-quality care. London: Kings Fund.

https://www.kingsfund.org.uk/sites/default/files/2020-

09/The\%20courage\%20of\%20compassion\%20full\%20report_0.pdf

Wong, C.A., \& Giallonardo, L.M. (2013). Authentic leadership and nurse-assessed adverse patient outcomes. Journal of Nursing Management, 21, 740752. https://doi.org/10.1111/jonm.12075.

Wong, C.A., \& CUMMINGS, G.G. (2007). The relationship between nursing leadership and patient outcomes: A literature review. Journal of Nursing Management (WileyBlackwell), 15, 508-521. https://doi.org/10.1111/j.1365-2834.2007.00723.x

Wong, C.A., Cummings, G.G., \& Ducharme, L. (2013). The relationship between nursing leadership and patient outcomes: a literature review update. Journal of Nursing Management (John Wiley \& Sons, Inc.), 21, 709-724.https://doi.org/10.1111/jonm.12116.

World Health Organisation. (2007). People-centred Health Care: A Policy Framework [online] [viewed 11 March 2020]. Retrieved from: tinyurl.com/WHO-PCCframework 
Table 1: The summary of the 10 included studies

\begin{tabular}{|c|c|c|c|c|c|c|c|}
\hline $\mathbf{S} / \mathbf{N}$ & $\begin{array}{l}\text { Author(s), } \\
\text { Year, Journal } \\
\text { and Title }\end{array}$ & $\begin{array}{l}\text { Study } \\
\text { design }\end{array}$ & Setting & Participants & $\begin{array}{l}\text { Leadership } \\
\text { styles }\end{array}$ & Mediators & Results \\
\hline 1 & $\begin{array}{l}\text { Squires et al. } \\
\text { (2010) } \\
\text { Journal of } \\
\text { Nursing } \\
\text { Management } \\
\text { The link between } \\
\text { leadership and } \\
\text { safety outcomes } \\
\text { in hospitals }\end{array}$ & $\begin{array}{l}\text { Cross- } \\
\text { sectional } \\
\text { survey }\end{array}$ & $\begin{array}{l}\text { RNs who } \\
\text { working in an } \\
\text { acute care } \\
\text { hospitals in } \\
\text { Ontario, } \\
\text { Canada. }\end{array}$ & $\begin{array}{l}266 \mathrm{RNs} \\
\text { worked in an } \\
\text { acute care } \\
\text { hospital }\end{array}$ & $\begin{array}{l}\text { Resonant } \\
\text { leadership }\end{array}$ & $\begin{array}{l}\text { - leader - nurse } \\
\text { relationship } \\
\text { - practice } \\
\text { environment } \\
\text { - safety } \\
\text { climate in the } \\
\text { unit }\end{array}$ & $\begin{array}{l}\text { - Nursing leaders can improve } \\
\text { patient safety outcomes } \\
\text { through fostering a quality } \\
\text { work environment } \\
\text { (Professional practice, } \\
\text { staffing, nursing process, RN- } \\
\text { MD collaboration, nursing } \\
\text { competency and schedule) and } \\
\text { positive safety climate }\end{array}$ \\
\hline
\end{tabular}




\begin{tabular}{|c|c|c|c|c|c|c|c|}
\hline $\mathbf{S} / \mathbf{N}$ & $\begin{array}{l}\text { Author(s), } \\
\text { Year, Journal } \\
\text { and Title }\end{array}$ & $\begin{array}{l}\text { Study } \\
\text { design }\end{array}$ & Setting & Participants & $\begin{array}{l}\text { Leadership } \\
\text { styles }\end{array}$ & Mediators & Results \\
\hline 2 & $\begin{array}{l}\text { Wong and } \\
\text { Giallonardo } \\
\text { (2013) } \\
\text { Journal of } \\
\text { Nursing } \\
\text { Management } \\
\text { Authentic } \\
\text { leadership and } \\
\text { nurse-assessed } \\
\text { adverse patient } \\
\text { outcomes }\end{array}$ & $\begin{array}{l}\text { Cross- } \\
\text { sectional } \\
\text { survey }\end{array}$ & $\begin{array}{l}\text { RNs working } \\
\text { in acute care } \\
\text { hospitals in } \\
\text { Ontario, } \\
\text { Canada }\end{array}$ & $\begin{array}{l}280 \mathrm{RNs} \\
\text { worked in } \\
\text { acute care } \\
\text { hospitals }\end{array}$ & $\begin{array}{l}\text { Authentic } \\
\text { leadership }\end{array}$ & $\begin{array}{l}\text { - trust in nurse } \\
\text { manager } \\
\text { - areas of } \\
\text { worklife }\end{array}$ & $\begin{array}{l}\text { - There is a association between } \\
\text { relational nursing leadership } \\
\text { and patient safety outcomes } \\
\text { - Authentic leadership could } \\
\text { reduced patient adverse events } \\
\text { through modifying nurses' } \\
\text { workplace condition that } \\
\text { foster nurses' trust in their } \\
\text { manager } \\
\text { - Nurse's reliability on their } \\
\text { manager and areas of worklife } \\
\text { served as mediators in this } \\
\text { process }\end{array}$ \\
\hline
\end{tabular}

This article is protected by copyright. All rights reserved 


\begin{tabular}{|c|c|c|c|c|c|c|c|}
\hline $\mathbf{S} / \mathbf{N}$ & $\begin{array}{l}\text { Author(s), } \\
\text { Year, Journal } \\
\text { and Title }\end{array}$ & $\begin{array}{l}\text { Study } \\
\text { design }\end{array}$ & Setting & Participants & $\begin{array}{l}\text { Leadership } \\
\text { styles }\end{array}$ & Mediators & Results \\
\hline 3 & $\begin{array}{l}\text { Boamah et al. } \\
(2018) \\
\text { Nursing Outlook } \\
\text { Effect of } \\
\text { transformational } \\
\text { leadership on job } \\
\text { satisfaction and } \\
\text { patient safety } \\
\text { outcomes }\end{array}$ & $\begin{array}{l}\text { Cross - } \\
\text { sectional } \\
\text { survey }\end{array}$ & $\begin{array}{l}\text { RNs working } \\
\text { in direct } \\
\text { patient care } \\
\text { in acute care } \\
\text { hospitals in } \\
\text { Ontario, } \\
\text { Canada }\end{array}$ & $\begin{array}{l}378 \mathrm{RNs} \\
\text { worked in } \\
\text { acute care } \\
\text { hospitals }\end{array}$ & $\begin{array}{l}\text { Transformat } \\
\text { ional } \\
\text { leadership }\end{array}$ & $\begin{array}{l}\text { - Structural } \\
\text { empowerment } \\
\text { - Job } \\
\text { satisfaction }\end{array}$ & $\begin{array}{l}\text { - Transformational leadership } \\
\text { showed significant indirect } \\
\text { effect on adverse patient } \\
\text { outcomes via structural } \\
\text { empowerment } \\
\text { - Transformational leadership } \\
\text { expressed a strong and } \\
\text { significant positive direct } \\
\text { effect on structural } \\
\text { empowerment, which in turn } \\
\text { improved nurses' work } \\
\text { contentment and lower patient } \\
\text { adverse events. Subsequently } \\
\text { nurses' happiness with their } \\
\text { work also contributed to } \\
\text { decreased patient adverse } \\
\text { events }\end{array}$ \\
\hline
\end{tabular}

This article is protected by copyright. All rights reserved 


\begin{tabular}{|c|c|c|c|c|c|c|c|}
\hline $\mathbf{S} / \mathbf{N}$ & $\begin{array}{l}\text { Author(s), } \\
\text { Year, Journal } \\
\text { and Title }\end{array}$ & $\begin{array}{l}\text { Study } \\
\text { design }\end{array}$ & Setting & Participants & $\begin{array}{l}\text { Leadership } \\
\text { styles }\end{array}$ & Mediators & Results \\
\hline 4 & $\begin{array}{l}\text { Boamah } 2018 \\
\text { Canadian Journal } \\
\text { of Nursing } \\
\text { Research } \\
\text { Linking } \\
\text { nursings' clinical } \\
\text { leadership to } \\
\text { patient care } \\
\text { quality: the role } \\
\text { of } \\
\text { transformational } \\
\text { leadership and } \\
\text { workplace } \\
\text { empowerment }\end{array}$ & $\begin{array}{l}\text { Cross- } \\
\text { sectional } \\
\text { survey }\end{array}$ & $\begin{array}{l}\text { RNs working } \\
\text { in direct } \\
\text { patient care } \\
\text { in acute care } \\
\text { hospitals in } \\
\text { Ontario, } \\
\text { Canada }\end{array}$ & $\begin{array}{l}378 \text { RNs } \\
\text { with direct } \\
\text { patient care } \\
\text { from acute } \\
\text { care hospitals }\end{array}$ & $\begin{array}{l}\text { Transformat } \\
\text { ional } \\
\text { leadership }\end{array}$ & $\begin{array}{l}\text { - Structural } \\
\text { empowerment } \\
\text { - staff nurse } \\
\text { clinical } \\
\text { leadership }\end{array}$ & $\begin{array}{l}\text { - Transformational leadership } \\
\text { has strong indirect association } \\
\text { with improved adverse patient } \\
\text { events } \\
\text { - Staff empowerment and } \\
\text { clinical leadership skill } \\
\text { mediated transformational } \\
\text { leadership negatively on } \\
\text { adverse patient outcomes } \\
\text { - Transformational leadership } \\
\text { has enhanced staff nurse } \\
\text { clinical leadership } \\
\text { development indirectly via } \\
\text { structural empowerment. } \\
\text { Subsequently, staff with strong } \\
\text { clinical leadership skill has } \\
\text { improved patient outcomes. }\end{array}$ \\
\hline
\end{tabular}

This article is protected by copyright. All rights reserved 


\begin{tabular}{|c|c|c|c|c|c|c|c|}
\hline $\mathbf{S} / \mathbf{N}$ & $\begin{array}{l}\text { Author(s), } \\
\text { Year, Journal } \\
\text { and Title }\end{array}$ & $\begin{array}{l}\text { Study } \\
\text { design }\end{array}$ & Setting & Participants & $\begin{array}{l}\text { Leadership } \\
\text { styles }\end{array}$ & Mediators & Results \\
\hline 5 & $\begin{array}{l}\text { Khanzada et al. } \\
\text { (2018) } \\
\text { Journal of Health } \\
\text { Education } \\
\text { Research \& } \\
\text { Development } \\
\text { Impact of } \\
\text { transformational } \\
\text { leadership on job } \\
\text { satisfaction and } \\
\text { patient safety } \\
\text { outcomes in } \\
\text { health sector of } \\
\text { Pakistan }\end{array}$ & $\begin{array}{l}\text { Cross- } \\
\text { sectional } \\
\text { survey }\end{array}$ & $\begin{array}{l}\text { RNs working } \\
\text { in direct } \\
\text { patient care } \\
\text { in critical } \\
\text { care hospitals } \\
\text { around } \\
\text { Rawalpindi, } \\
\text { Islamabad }\end{array}$ & $\begin{array}{l}358 \text { RNs } \\
\text { with direct } \\
\text { patient care } \\
\text { from critical } \\
\text { care hospitals }\end{array}$ & $\begin{array}{l}\text { Transformat } \\
\text { ional } \\
\text { leadership }\end{array}$ & $\begin{array}{l}\text { - Structural } \\
\text { empowerment } \\
\text { - Job } \\
\text { satisfaction }\end{array}$ & $\begin{array}{l}\text { - Transformational leadership } \\
\text { contributed a positive } \\
\text { influence on workplace } \\
\text { empowerment, which further } \\
\text { promoted nurse's happiness on } \\
\text { their work and lower episodes } \\
\text { of adverse patient events. } \\
\text { Nurses' higher Job satisfaction } \\
\text { also directly reduced patient } \\
\text { adverse outcomes } \\
\text { - Staff empowerment and work } \\
\text { contentment mediated } \\
\text { transformational leadership on } \\
\text { adverse patient events } \\
\text { negatively }\end{array}$ \\
\hline
\end{tabular}

This article is protected by copyright. All rights reserved 


\begin{tabular}{|c|c|c|c|c|c|c|c|}
\hline $\mathbf{S} / \mathbf{N}$ & $\begin{array}{l}\text { Author(s), } \\
\text { Year, Journal } \\
\text { and Title }\end{array}$ & $\begin{array}{l}\text { Study } \\
\text { design }\end{array}$ & Setting & Participants & $\begin{array}{l}\text { Leadership } \\
\text { styles }\end{array}$ & Mediators & Results \\
\hline 6 & $\begin{array}{l}\text { Asif et al. (2019) } \\
\text { International } \\
\text { Journal of } \\
\text { Environmental } \\
\text { Research and } \\
\text { Public Health } \\
\text { Linking } \\
\text { Transformational } \\
\text { leadership with } \\
\text { nurse-assessed } \\
\text { adverse patient } \\
\text { outcomes and } \\
\text { the quality of } \\
\text { care: assessing } \\
\text { the role of job } \\
\text { satisfaction and } \\
\text { structural }\end{array}$ & $\begin{array}{l}\text { Cross- } \\
\text { sectional } \\
\text { survey }\end{array}$ & $\begin{array}{l}\text { Female RNs } \\
\text { working in } \\
17 \\
\text { government } \\
\text { hospitals in } \\
\text { Pakistan }\end{array}$ & $\begin{array}{l}386 \mathrm{RNs} \\
\text { working in } \\
\text { government } \\
\text { hospitals }\end{array}$ & $\begin{array}{l}\text { Transformat } \\
\text { ional } \\
\text { leadership }\end{array}$ & $\begin{array}{l}\text { - Structural } \\
\text { empowerment } \\
\text { - Job } \\
\text { satisfaction }\end{array}$ & $\begin{array}{l}\text { - A strong relationship exists } \\
\text { between transformational } \\
\text { leadership and nurse-reported } \\
\text { adverse patient events and } \\
\text { patient care quality. structural } \\
\text { empowerment and job } \\
\text { satisfaction were mediators in } \\
\text { this process } \\
\text { - Both structural empowerment } \\
\text { and job satisfaction showed } \\
\text { significant negative mediating } \\
\text { impact on transformational } \\
\text { leadership towards patient } \\
\text { adverse events } \\
\text { - Both structural empowerment } \\
\text { and job satisfaction had } \\
\text { significant positive mediating } \\
\text { impact on transformational } \\
\text { leadership towards quality of }\end{array}$ \\
\hline
\end{tabular}

This article is protected by copyright. All rights reserved 


\begin{tabular}{|c|c|c|c|c|c|c|c|}
\hline $\mathbf{S} / \mathbf{N}$ & $\begin{array}{l}\text { Author(s), } \\
\text { Year, Journal } \\
\text { and Title }\end{array}$ & $\begin{array}{l}\text { Study } \\
\text { design }\end{array}$ & Setting & Participants & $\begin{array}{l}\text { Leadership } \\
\text { styles }\end{array}$ & Mediators & Results \\
\hline & empowerment & & & & & & $\begin{array}{l}\text { care, which logically enhanced } \\
\text { the frequency of patient } \\
\text { adverse events }\end{array}$ \\
\hline
\end{tabular}

This article is protected by copyright. All rights reserved 


\begin{tabular}{|c|c|c|c|c|c|c|c|}
\hline $\mathbf{S} / \mathbf{N}$ & $\begin{array}{l}\text { Author(s), } \\
\text { Year, Journal } \\
\text { and Title }\end{array}$ & $\begin{array}{l}\text { Study } \\
\text { design }\end{array}$ & Setting & Participants & $\begin{array}{l}\text { Leadership } \\
\text { styles }\end{array}$ & Mediators & Results \\
\hline 7 & $\begin{array}{l}\text { Higgins (2015) } \\
\text { ProQuest } \\
\text { published } \\
\text { doctoral } \\
\text { dissertation } \\
\text { The influence of } \\
\text { nurse manager } \\
\text { transformational } \\
\text { leadership on } \\
\text { nurse and patient } \\
\text { outcomes: } \\
\text { mediating effects } \\
\text { of supportive } \\
\text { practice } \\
\text { environments, } \\
\text { organizational } \\
\text { citizenship }\end{array}$ & $\begin{array}{l}\text { Predictiv } \\
\text { e non- } \\
\text { experim } \\
\text { ental }\end{array}$ & $\begin{array}{l}\text { Nurses } \\
\text { working in } \\
\text { inpatient } \\
\text { units } \\
\text { including: } \\
\text { medical, } \\
\text { surgical, } \\
\text { critical care, } \\
\text { maternal } \\
\text { child, } \\
\text { rehabilitation, } \\
\text { complex } \\
\text { continue care } \\
\text { and mental } \\
\text { health within } \\
\text { a hospital in } \\
\text { Ontario, } \\
\text { Canada }\end{array}$ & $\begin{array}{l}1678 \mathrm{RNs} \\
\text { and RPNs } \\
\text { working on } \\
\text { inpatient } \\
\text { units within a } \\
\text { hospital }\end{array}$ & $\begin{array}{l}\text { Transformat } \\
\text { ion } \\
\text { leadership }\end{array}$ & $\begin{array}{l}\text { - Supportive } \\
\text { practice } \\
\text { environment } \\
\text { - } \\
\text { Organizational } \\
\text { citizenship } \\
\text { behaviors }\end{array}$ & $\begin{array}{l}\text { - Transformational leadership } \\
\text { style showed more influence } \\
\text { on supportive nursing practice } \\
\text { environment in comparison to } \\
\text { transactional leadership style } \\
\text { did } \\
\text { - Transformational leadership } \\
\text { could optimize staff practice } \\
\text { setting and patient safety } \\
\text { outcomes } \\
\text { - Transformational leadership } \\
\text { negatively affected patient } \\
\text { adverse events by the } \\
\text { mediating role of supportive } \\
\text { practice environment and } \\
\text { organizational citizenship } \\
\text { behaviors }\end{array}$ \\
\hline
\end{tabular}

This article is protected by copyright. All rights reserved 


\begin{tabular}{|l|l|l|l|l|l|l|l|}
\hline S/N & $\begin{array}{l}\text { Author(s), } \\
\text { Year, Journal } \\
\text { and Title }\end{array}$ & $\begin{array}{l}\text { Study } \\
\text { design }\end{array}$ & Setting & Participants & $\begin{array}{l}\text { Leadership } \\
\text { styles }\end{array}$ & Mediators & Results \\
\hline $\begin{array}{l}\text { behavious, } \\
\text { patient safety } \\
\text { culture and nurse } \\
\text { job satisfaction }\end{array}$ & & & & & & & \\
& & & & & & & \\
& & & & & & & \\
& & & & & & & \\
& & & & & & \\
\end{tabular}

This article is protected by copyright. All rights reserved 


\begin{tabular}{|c|c|c|c|c|c|c|c|}
\hline $\mathbf{S} / \mathbf{N}$ & $\begin{array}{l}\text { Author(s), } \\
\text { Year, Journal } \\
\text { and Title }\end{array}$ & $\begin{array}{l}\text { Study } \\
\text { design }\end{array}$ & Setting & Participants & $\begin{array}{l}\text { Leadership } \\
\text { styles }\end{array}$ & Mediators & Results \\
\hline 8 & $\begin{array}{l}\text { Lappalainen et } \\
\text { al. (2019) } \\
\text { Standard Journal } \\
\text { of Caring } \\
\text { Sciences } \\
\text { The relationship } \\
\text { between nurse } \\
\text { manager's } \\
\text { transformational } \\
\text { leadership style } \\
\text { and medication } \\
\text { safety }\end{array}$ & $\begin{array}{l}\text { Descript } \\
\text { ive } \\
\text { cross- } \\
\text { sectional } \\
\text { study }\end{array}$ & $\begin{array}{l}\text { RNs working } \\
\text { in three } \\
\text { different } \\
\text { Finnish } \\
\text { Hospitals } \\
\text { comprising of } \\
33 \text { inpatient } \\
\text { wards }\end{array}$ & $\begin{array}{l}161 \mathrm{RNs} \\
\text { from three } \\
\text { Finnish } \\
\text { hospitals }\end{array}$ & $\begin{array}{l}\text { Transformat } \\
\text { ional } \\
\text { leadership }\end{array}$ & $\begin{array}{l}\text { - Nursing } \\
\text { process } \\
\text { management }\end{array}$ & $\begin{array}{l}\text { - Transformational leadership } \\
\text { can promote medication } \\
\text { safety, which is major threat to } \\
\text { patient safety } \\
\text { - Management of nursing } \\
\text { processes significantly } \\
\text { medicated transformational } \\
\text { leadership towards patient } \\
\text { medication safety outcome. }\end{array}$ \\
\hline 9 & $\begin{array}{l}\text { Kim et al. (2020) } \\
\text { Journal of } \\
\text { Research in } \\
\text { Nursing }\end{array}$ & $\begin{array}{l}\text { Cross- } \\
\text { sectional } \\
\text { descripti } \\
\text { ve }\end{array}$ & $\begin{array}{l}\text { Nurses } \\
\text { working in } \\
\text { secondary or } \\
\text { tertiary } \\
\text { hospitals in }\end{array}$ & $\begin{array}{l}153 \mathrm{RNs} \\
\text { from } \\
\text { secondary or } \\
\text { tertiary } \\
\text { hospitals }\end{array}$ & $\begin{array}{l}\text { Transformat } \\
\text { ional } \\
\text { leadership }\end{array}$ & $\begin{array}{l}\text { - Perceived } \\
\text { benefits of } \\
\text { safety } \\
\text { medication } \\
\text { system use }\end{array}$ & $\begin{array}{l}\text { - Transformational leadership } \\
\text { promoted perceived } \\
\text { advantages of safety } \\
\text { medication system utilisation } \\
\text { that in turn to contribute to a }\end{array}$ \\
\hline
\end{tabular}

This article is protected by copyright. All rights reserved 


\begin{tabular}{|c|c|c|c|c|c|c|c|}
\hline $\mathbf{S} / \mathbf{N}$ & $\begin{array}{l}\text { Author(s), } \\
\text { Year, Journal } \\
\text { and Title }\end{array}$ & $\begin{array}{l}\text { Study } \\
\text { design }\end{array}$ & Setting & Participants & $\begin{array}{l}\text { Leadership } \\
\text { styles }\end{array}$ & Mediators & Results \\
\hline & $\begin{array}{l}\text { Mediating role } \\
\text { of the perceived } \\
\text { benefits of using } \\
\text { a medication } \\
\text { safety system in } \\
\text { the relationship } \\
\text { between } \\
\text { transformational } \\
\text { leadership and } \\
\text { the medication- } \\
\text { error } \\
\text { management } \\
\text { climate }\end{array}$ & & Korea & & & & $\begin{array}{l}\text { improved medication error- } \\
\text { management culture. } \\
\text { - Perceived improvement of } \\
\text { safety medication system use } \\
\text { was the mediator in this } \\
\text { process }\end{array}$ \\
\hline
\end{tabular}

This article is protected by copyright. All rights reserved 


\begin{tabular}{|c|c|c|c|c|c|c|c|}
\hline $\mathbf{S} / \mathbf{N}$ & $\begin{array}{l}\text { Author(s), } \\
\text { Year, Journal } \\
\text { and Title }\end{array}$ & $\begin{array}{l}\text { Study } \\
\text { design }\end{array}$ & Setting & Participants & $\begin{array}{l}\text { Leadership } \\
\text { styles }\end{array}$ & Mediators & Results \\
\hline 10 & $\begin{array}{l}\text { Laschinger and } \\
\text { Leiter (2006) } \\
\text { The Journal of } \\
\text { Nursing } \\
\text { Administration } \\
\text { The impact of } \\
\text { nursing work } \\
\text { environment on } \\
\text { patient safety } \\
\text { outcomes }\end{array}$ & $\begin{array}{l}\text { Cross- } \\
\text { sectional } \\
\text { survey }\end{array}$ & $\begin{array}{l}\text { Hospital- } \\
\text { based nurses } \\
\text { in Ontario } \\
\text { and Alberta, } \\
\text { Canada }\end{array}$ & $\begin{array}{l}8597 \\
\text { hospital- } \\
\text { based nurses }\end{array}$ & $\begin{array}{l}\text { Nursing } \\
\text { leadership } \\
\text { (not specify) }\end{array}$ & $\begin{array}{l}\text { - Quality of } \\
\text { worklife } \\
\text { - Nurses } \\
\text { emotional } \\
\text { exhaustion and } \\
\text { personal } \\
\text { accomplishme } \\
\text { nt }\end{array}$ & $\begin{array}{l}\text { - Nursing leadership revealed a } \\
\text { crucial role in staff quality of } \\
\text { worklife such as participation } \\
\text { in policy making, manpower, } \\
\text { support for nursing model of } \\
\text { care and rapport with } \\
\text { physician } \\
\text { - Staffing level and nursing } \\
\text { model of care directly } \\
\text { influenced nurses' emotional } \\
\text { exhaustion and individual } \\
\text { achievement, which } \\
\text { subsequently affect patient } \\
\text { safety outcomes } \\
\text { - Nursing leadership had } \\
\text { significant impact on patient } \\
\text { safety outcomes through } \\
\text { optimisation of practice } \\
\text { environment to minimise staff }\end{array}$ \\
\hline
\end{tabular}

This article is protected by copyright. All rights reserved 


\begin{tabular}{|l|l|l|l|l|l|l|l|}
\hline S/N & $\begin{array}{l}\text { Author(s), } \\
\text { Year, Journal } \\
\text { and Title }\end{array}$ & $\begin{array}{l}\text { Study } \\
\text { design }\end{array}$ & Setting & Participants & $\begin{array}{l}\text { Leadership } \\
\text { styles }\end{array}$ & Mediators & Results \\
\hline & & & & & & burnout \\
& & & & & & & \\
& & & & & & & \\
& & & & & & & \\
\end{tabular}

This article is protected by copyright. All rights reserved 
Figure 1: PRISMA (2009) Flow diagram for search and retrieval process

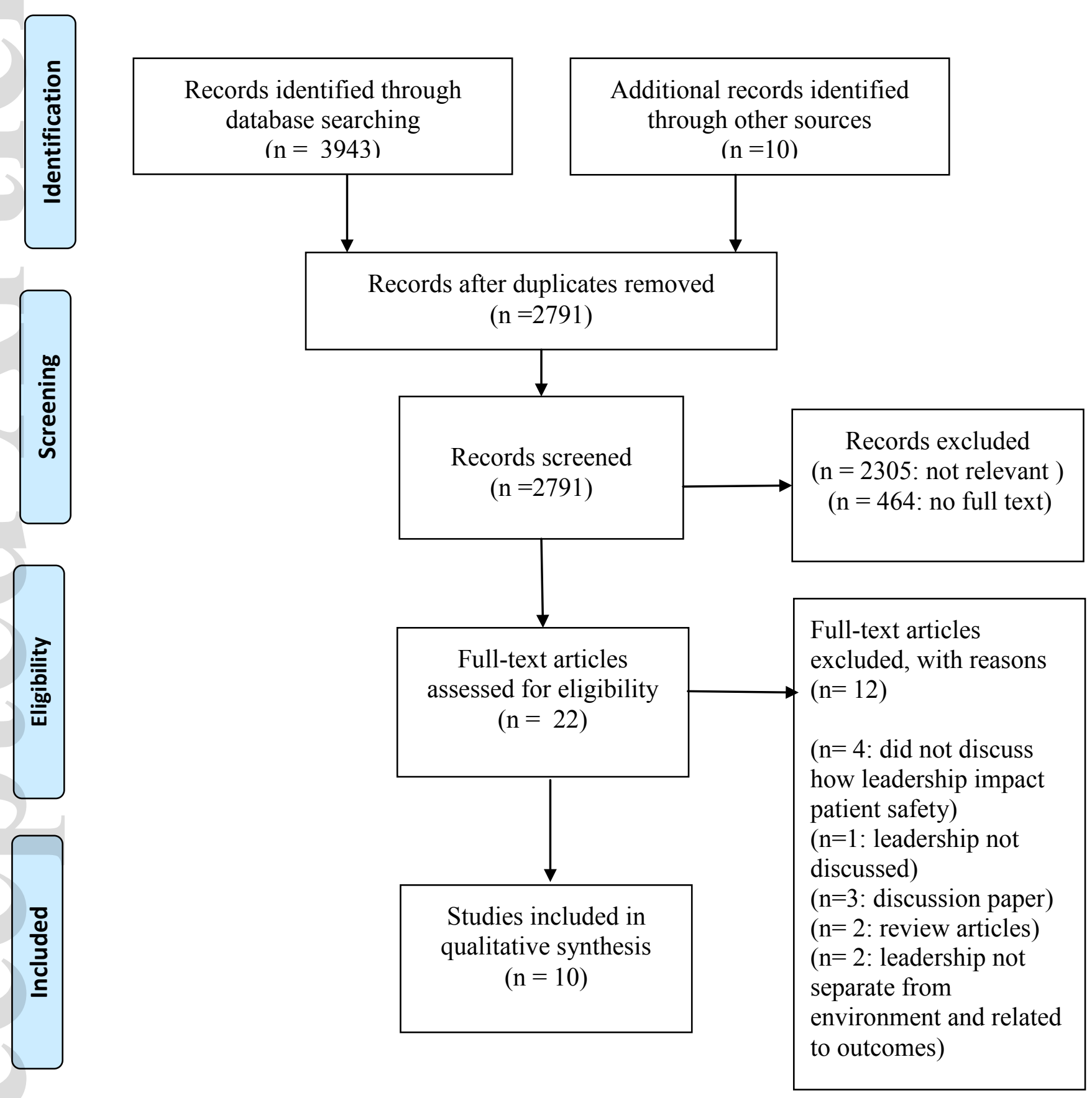


Figure 2 Person-centred Practice Framework (McCormack and McCance 2017)

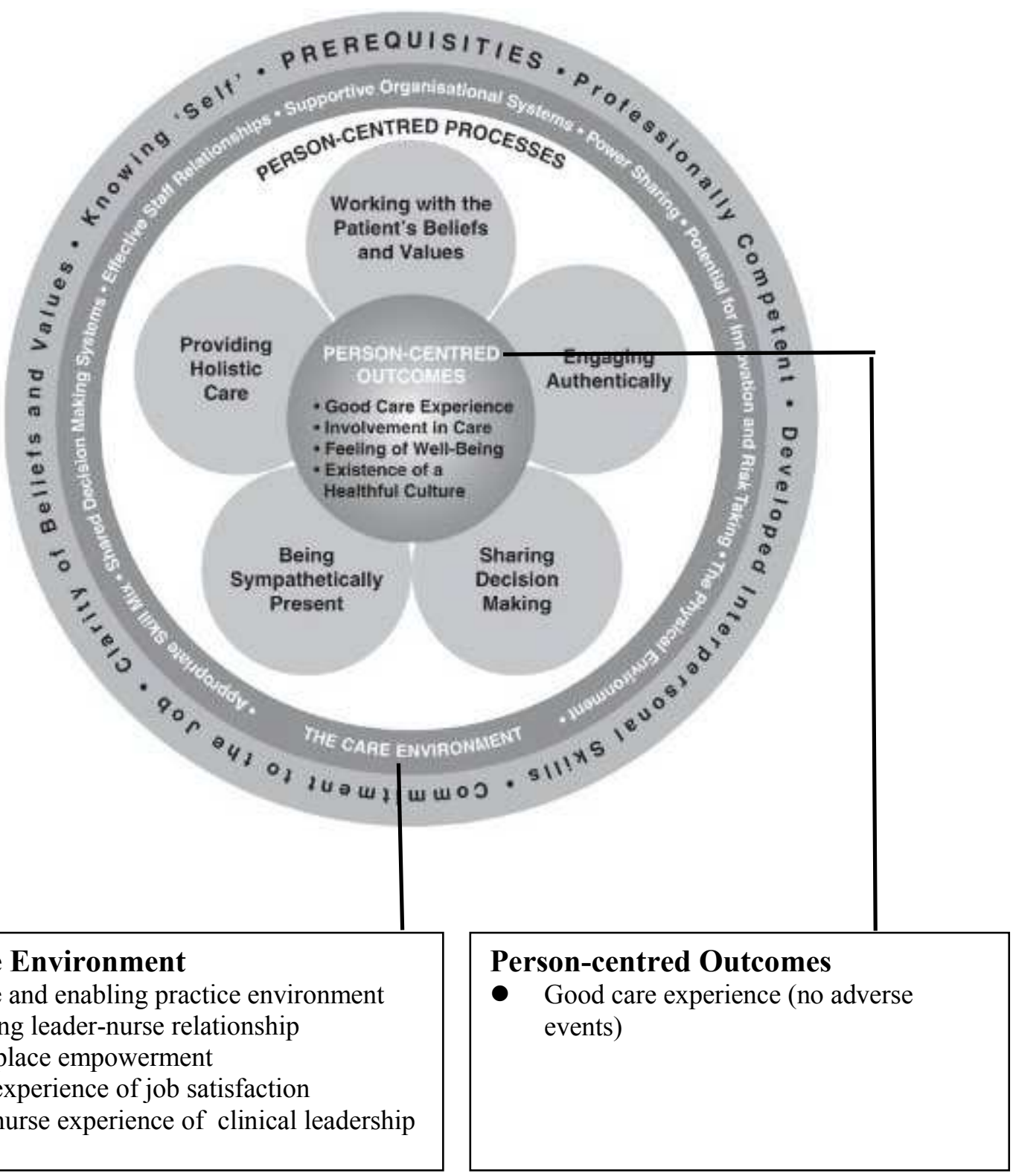

This article is protected by copyright. All rights reserved 


\section{Box 1: Search Inclusion Criteria}

\section{Inclusion criteria}

- Published research studies that addressed the mechanism through which nursing leadership impacted patient safety outcomes were included

- Qualitative or quantitative studies were included

- The study has to discuss the mechanism or mediating effect between nursing leadership and patient safety. This excluded studies that only evaluated the relationship between nursing leadership and patient safety outcomes

- There was no restriction on research design

- English-only articles were reviewed.

- All studies were published and dating from 2004 to 2019. 